\title{
Effect of foliar application of humic acid fortified with zinc and boron on growth and yield of capsicum
}

\section{S.N. AVINASH, C. A. SRINIVASAMURTHY AND S. BHASKAR}

Received : 23.09.2017; Revised : 09.11.2017; Accepted : 19.11.2017

\section{MEMBERS OF RESEARCH FORUM:}

Corresponding author :

S.N. AVINASH, Department of Soil Science and Agricultural Sciences, University of Agricultural Sciences, GKVK, BENGALURU (KARNATAKA) INDIA

Email: avinashsn0005@gmail.com

Co-authors : C.A. SRINIVASAMURTHY, Central Agricultural University IMPHAL (MANIPUR) INDIA

Email: casmurthy@yahoo.com

S. BHASKAR, Indian Council of Agricultural Research, NEW DELHI, INDIA

Email: drbhaskar63@gmail.com

\section{Summary}

A field experiment was conducted during Kharif 2015 in a farmer's field to study the effect of foliar spray of humic acid fortified with zinc and boron on growth and yield of capsicum. The experiment was laid out in Randomized Complete Block Design with 16 treatment combinations. The results revealed that significantly higher plant height, total number of branches plant ${ }^{-1}$, number of leaves per plant ${ }^{-1}$, SPAD meter reading, dry matter production plant ${ }^{-1}$, Number of fruits plant ${ }^{-1}$, yield plant ${ }^{-1}$, per cent fruit set, weight of ten fruits, fruit yield $\left(54.23 \mathrm{t} \mathrm{ha}^{-1}\right)$ were $^{-}$ recorded in treatment receiving RDF + FYM applied to soil and 3 foliar sprays of zinc fortified humic acid extracted from poultry manure at 0.50 per cent and it was at par with the treatment receiving RDF + FYM applied to soil and 3 foliar sprays of zinc fortified humic acid extracted from coffee pulp at 0.50 per cent.

Key words : Humic acid, Zinc, Boron, Capsicum, Poultry manure, Coffee pulp

How to cite this article : Avinash, S.N., Srinivasamurthy, C.A. and Bhaskar, S. (2017). Effect of foliar application of humic acid fortified with zinc and boron on growth and yield of capsicum. Asian J. Soil Sci., 12 (2) : 283-289 : DOI : 10.15740/HAS/AJSS/12.2/283-289. 